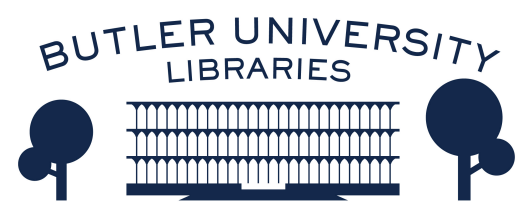

Journal of Hindu-Christian Studies

\title{
Book Review: "Religious Dimensions of Child and Family Life: Reflections on the UN Convention on the Rights of the Child"
}

Cromwell Crawford

Follow this and additional works at: https://digitalcommons.butler.edu/jhcs

Part of the Religion Commons

\section{Recommended Citation}

Crawford, Cromwell (1998) "Book Review: "Religious Dimensions of Child and Family Life: Reflections on the UN Convention on the Rights of the Child"," Journal of Hindu-Christian Studies: Vol. 11, Article 15.

Available at: https://doi.org/10.7825/2164-6279.1188

The Journal of Hindu-Christian Studies is a publication of the Society for Hindu-Christian Studies. The digital version is made available by Digital Commons @ Butler University. For questions about the Journal or the Society, please contact cbauman@butler.edu. For more information about Digital Commons @ Butler University, please contact digitalscholarship@butler.edu. 


\section{Religious Dimensions of Child and Family Life: Reflections on the UN Convention on the Rights of the Child. Harold Coward and} Philip Cook, eds. Victoria: Centre for Studies in Religion and Society, University of Victoria, 1996, 200 pp.

THIS BOOK EXAMINES the role and status of the child and family life from the perspectives of eight religious traditions in relation to the United Nations Convention on the Rights of the Child (UNCRC). Its purpose is to clarify specific areas in which the diverse religions can promote the UN document, and where they disagree. The volume is slim, but it packs an array of concrete ideas and information, particularly useful for work in applied ethics.

The topic is timely because of unabated acts of premeditated violence against children. Philip Cook provides an excellent Introduction which virtually serves as an abridged version of the book. He commends the Convention for having "raised the level of discussion on the importance of placing children first", for providing "a moral and ethical framework to promote children's well-being both at the grass roots and in national legislations", and for serving as "a benchmark with which to measure a nation's progress in providing and advocating for its most vulnerable". On the down side, Cook points out that "the Achilles heel of the Convention lies in the various interpretations that can be drawn from many of the articles which are broadly written and open to misinterpretation". Problems arise when the UNCRC advocates individuals ' rights which actually weaken the value of family unity, and when the UNCRC promotes children's participation in decision making.

Cook sets the tone of the book by emphasizing that the implementation of the UNCRC will require its creative integration with traditional cultural and moral beliefs on national and local levels. His concern is well taken:

many children's programs in developed and developing countries are still designed with little thought to cultural or religious diversity even though the importance of culture is highlighted in articles within the Convention. Though some progress has been made in creating programs that integrate positive aspects of traditional wisdom, there remains an equal or greater number of programs adopting "scientific approaches" that conflict with religious beliefs regarding the place of children in society.

Writing from a Christian perspective, Terence R. Anderson differs with Muslim Lababidy's judgment as to the usefulness of the UNCRC as an instrument for developing public policy capable of protecting children. After careful debate, he concedes that the document should be credited for provisions that serve as bulwarks against clearly identified forms of child abuse, but the trouble is that these very provisions lie within "a framework of individual rights used to legitimate a kind and degree of state interference with the family which could seriously undermine the strength of marriages and families so essential to the true well-being of children".

By obvious oversight, Vasudha Narayanan is not mentioned in the Introduction, but that does not diminish the importance of her Hindu response to the UNCRC. The many facts and figures she presents make for some degree of confusion. The chapter unfolds with a distinctively indigenous quality. Perhaps the humanistic elements of Hinduism which would support the UNCRC could have been portrayed more fully and accurately by recourse to philosophic texts to balance the ritual manuals Narayanan chiefly relies upon. 
First, she cites various infractions of the UNCRC in today's India due to discrimination in terms of caste, gender, and geographic origin. On the positive side she examines rituals, story telling, and role playing as important features for adults and children. Through these means "society tries to empower the potential child spiritually and seek for it a long life, strength and wisdom. Story telling and role playing enhance the child's knowledge of the tradition and shapes its world view". She concludes by observing that notwithstanding "patriarchal strains" the Hindu tradition does provide "the internal resources to combat the discrimination against children based on gender".

In his Conclusion, Harold Coward ignites a dilemma, flickering through the text - namely, how a specific religious view of the family can co-exist with the liberal democratic assumptions of the UN
Convention. For a solution to the dilemma, he draws on the political theories of Charles Taylor and finds in his arguments a corrective to the liberal presuppositions of the UNCRC. Readers will find Coward's own thesis much more convincing than the case study of a North American Aboriginal family he uses to examine the issues. In the final section, Coward shifts from critique to commendation with a summary of how the UNCRC principles in respect to girls and women are hailed by the religions as valid criticisms of their own traditional practices.

The chief asset of this volume is its capacity to serve as a resource for communities that must face the challenge of implementing the UNCRC through activities that harmonize with the beliefs and values of traditional religious cultures.

Cromwell Crawford

University of Hawaii

\section{The Colors of Violence: Cultural Identities, Religion and Conflict. Sudhir Kakar. Chicago: University of Chicago Press, 1996, xiii + 217pp.}

THE STRENGTH OF this book is in its psychological analysis of the causes of communal riots in India. It is an extended case study of the Hindu-Muslim riots in Hyderabad in 1990, triggered by the Babri Masjid-Ramjanmabhoomi conflict. The book proceeds by way of interpretive interviews with both Hindu and Muslim leaders of violent mobs as well as with the victims of violence. Examples are also given of a Muslim family giving a Hindu family shelter and saving their lives during a riot. The author analyses friendships that cross communal divides. A convincing picture is presented of how communal violence can change forever the harmonious pattern of peaceful coexistence that crossed religious lines and typified many Indian communities in the past.

While focused on a Hindu-Muslim riot, the psychological dynamics uncovered apply as well to hostility between any religious communities. On an individual level it is the attitude expressed toward the Other who is sharing one's space in the community whether the Other is Muslim,. Sikh, or Christian, from a majority Hindu perspective, for example. The dynamic in India has been heightened since the time of partition. The psychological mechanism that Kakar most often uncovers is Freudian "projection". For example, seeing Muslims as "dirty" and as "sexual animals" is a projection by Hindus of their own instinctuality onto the Muslim. "other" or "out group". Kakar suggests that modernization prompts individuals increasingly to seek membership in groups with absolute value systems and with little tolerance for deviation from their norms - as 